\title{
AOSIS v The World: A Blueprint for the First International Multi-Party Climate Change Case
}

\author{
Benjamin Norman Forbes LL.M \\ DOI: $10.21827 /$ GroJIL.8.2.200-227
}

\section{Keywords:}

CLIMATE CHANGE; LITIGATION; JURISDICTION; ALLIANCE OF SMALL ISLAND DEVELOPING STATES

\begin{abstract}
This article is innovative in providing a Blueprint for bringing the first international multiparty climate change case. The Blueprint allows for AOSIS member states to bring a number of group claims against a Respondent Pool made up of the world's leading greenhouse gas emitters, before a variety of international bodies, on a variety of legal bases. International litigation presents substantial jurisdictional barriers, not least in regard to climate change litigation. It is these barriers that necessitate the group litigation strategy advocated for here. Specifically, the article envisages proceedings before the ICJ, ITLOS, and UNCLOS arbitral tribunals. The legal bases that the Blueprint requires are inventoried, however the focus is on the jurisdictional issues of the bodies. The practicalities involved in AOSIS bringing group cases before each body are explored and solutions for overcoming the jurisdictional barriers of each are offered. Ultimately, the article shows that the jurisdictional barriers are far from insurmountable, with the Blueprint allowing for all AOSIS member states to be involved in proceedings, before at least one body, against at least forty-eight respondents, including the US, China, and the EU.
\end{abstract}

\section{Introduction}

"W] have served as ports for trade and of conquest, and as both bases and targets for the missiles of war. Today, as we confront climate change, we find ourselves effectively in the same role, not of our choosing; facing a threat, not of our making.' ${ }^{1}$

Ever since its first assessment report, the Intergovernmental Panel on Climate Change (IPCC) has recognised Small Island Developing States (SIDS) as being highly vulnerable to climate change, notably sea level rise. ${ }^{2}$ In 1990 it stated that a $30-50 \mathrm{~cm}$ sea level rise (projected by 2050) would threaten low islands, while a one-meter rise by 2100 would 'render some island countries uninhabitable'. ${ }^{3}$ More than twenty years later, the IPCC's latest assessment report continued to confirm the high level of vulnerability of SIDS, pointing out that while SIDS 'represent only a fraction of total global damage projected to occur as a result of a SLR [sea-level rise] of $1 \mathrm{~m}$ by 2100 , the actual damage costs for the

* Benjamin Norman Forbes LL.M, University of Groningen.

1 Tuiloma N Slade (former AOSIS Vice-Chairman) in a speech to the High-Level Segment of the First Conference of Parties to the UNFCCC quoted in Epsen Ronneberg, 'Small Islands and the Big Issue: Climate Change and the role of the Alliance of Small Island States' in Kevin Gray, Richard Tarasofsky and Cinnamon Carlarne (eds), The Oxford Handbook of International Climate Change Law (OUP 2016) 762, 764.

2 Categories of high vulnerability include small islands. See Intergovernmental Panel on Climate Change, 'Climate Change: The IPCC Impacts Assessment' (Report of Working Group II, Australian Government Publishing Service 1990) 21.

3 IPCC, 'Policymakers' Summary' 4 $<$ https://www.ipcc.ch/site/assets/uploads/2018/03/ipcc_far_wg_II_spm.pdf> accessed 30 December 2020.

This work is licensed under the Creative Commons Attribution-NonCommercial-NoDerivatives 4.0 International License. To view a copy of this license, visit http://creativecommons.org/licenses/by-nc-nd/4.0/. 
small island states is enormous in relation to the size of their economics, with several small island nations being included in the group of 10 countries with the highest relative impact projected for $2100{ }^{\prime}$.

It is no wonder then that a number of SIDS have previously threatened climate litigation, such as Tuvalu, Palau, and most recently Vanuatu. ${ }^{5}$ However, Tuvalu and Palau's threats appear to have been dropped, and it is unclear whether Vanuatu intends to follow through on its threat and actually commence litigation. While any climate change case faces challenges at the merits stage, SIDS face substantial jurisdictional barriers in even commencing proceedings before an international court or tribunal. With ever more convincing scientific consensus around the causes and effects of climate change, perhaps it is the jurisdictional barriers and not the challenges posed at the merits stage that have so far quelled SIDS litigation threats. This article examines these jurisdictional barriers and seeks to show that they are not as insurmountable as they may at first appear. In doing so, the article is innovative in providing a Blueprint for the first international multi-party climate change case.

At the heart of the Blueprint is the Alliance of Small Island Developing States (AOSIS), with the author advocating that AOSIS members build on their history of success in working together in relation to climate change to bring a multi-party claim against a group of high emitting states across multiple international fora. A group litigation strategy allows AOSIS to overcome the jurisdictional barriers that would be faced by many of its members if they attempted to bring a case alone. AOSIS can utilise both the International Court of Justice (ICJ) and the dispute settlement procedure under the United Nations Convention on the Law of the Sea (UNCLOS) ${ }^{6}$ to bring proceedings against at least fortyeight respondents, from a 'Respondent Pool' that is constructed in Section 3, including the two biggest greenhouse gas (GHG) emitters, the US and China, as well as the European Union (EU). ${ }^{7}$ While the final decision on who to include as respondents lies with AOSIS, the Blueprint makes it possible to include the entire Respondent Pool in proceedings, guaranteeing that each member, bar one, can definitely be involved in proceedings before at least one court or tribunal. The one exception is Turkey, which can nevertheless potentially be involved through the solutions offered in Section 4. Importantly, the evasive high emitting US and China are not excluded, nor is the interesting option of the EU.

Section 2 illustrates why AOSIS are suitable climate change litigants, charting their collective successes in climate change negotiations and evidencing their existing desires for pursuing litigation. The Section then compiles a Respondent Pool of forty-eight states plus the EU, for AOSIS to consider and choose respondents from. Finally, the Section debunks the common argument that some high emitting states should be exempted from climate change litigation due to their economic and development status and the argument that responsibility should be borne by more developed states due to their historical emissions.

4 IPCC, 'Climate Change 2014: Impacts, Adaptation, and Vulnerability' (Working Group II's contribution to the Fifth Assessment Report, 2014) Part B, 1618.

5 See Rebecca Jacobs, 'Treading Deep Waters: Substantive Law Issues in Tuvalu's Threat to Sue the United States in the International Court of Justice' 14 Pacific Rim Law and Policy Journal (2005) 103; 'Palau seeks UN World Court opinion on damage caused by greenhouse gases' (UN News, 22 September 2011) $<$ https://news.un.org/en/story/2011/09/388202\#.Ur2V2Bk-YaJ> accessed 30 December 2020; Lisa Cox, 'Vanuatu says it may sue fossil fuel companies and other countries over climate change' (The Guardian, 22 May 2019) <https://www.theguardian.com/world/2018/nov/22/vanuatu-says-it-maysue-fossil-fuel-companies-and-other-countries-over-climate-change> accessed 30 December 2020.

6 United Nations Convention on the Law of the Sea (adopted 10 December 1982, entered into force 16 November 1994) 1833 UNTS 3 (UNCLOS).

7 The thesis envisages initiating proceedings against forty-eight States and the EU, however, Turkey is the only State that AOSIS is unable to guarantee including in proceedings before at least one court or tribunal. 
The method of construction of the Respondent Pool strikes a balance between capturing the most desirable states and providing a sound legal basis for their inclusion in proceedings.

Section 3 briefly discusses the legal bases that the Blueprint envisages invoking. This article is concerned with providing a Blueprint for overcoming the jurisdictional barriers to international climate change litigation and does not intend to analyse the merits of the legal arguments that would be involved. ${ }^{8}$ Indeed, the latter has been extensively written about elsewhere and this article is informed by such literature, while the former remains a gap in existing scholarship which the article seeks to fill. Nevertheless, in order to provide legal context for the litigation proceedings, it is helpful to at least compile an inventory of legal bases. This is because the Blueprint envisages AOSIS invoking a range of legal arguments in order for all AOSIS members to bring claims against the full Respondent Pool. These arguments are drawn from the climate change treaty regime, the law of the sea regime, and customary international law. However, the Section limits itself to an inventory, and stops short of pondering the ultimate success or failure of such arguments, suffice to say that the author is optimistic in this regard.

Section 4 discusses the jurisdictional rules of the ICJ and the UNCLOS Part XV dispute settlement procedure, the barriers to climate litigation that these present, and how they can be overcome. The Section takes a step by step approach in detailing which applicants and respondents can be involved at which forum and how, beginning with the ICJ, moving to ITLOS, and finally to the arbitral and special arbitral tribunals.

8 For fuller analysis of the legal arguments involved in international climate change litigation see Laura Horn, 'Is Litigation an Effective Weapon for Pacific Island Nations in the War Against Climate Change?' (2009) 12(1) Asia Pacific Journal of Environmental Law 169; Luke Elborough, 'International Climate Change Litigation: Limitations and Possibilities for International Adjudication and Arbitration in Addressing the Challenge of Climate Change' (2018) 21 New Zealand Journal of Environmental Law 89; M Wilder, 'Well Below 2C' (2016) 20 Law Society of New South Wales Journal 24; Daniel Bodansky, 'Paris Climate Change Agreement: A New Hope' (2016) 110(2) American Journal of International Law 2888; M Mace, 'Mitigation Commitments under the Paris Agreement and the Way Forward' (2016) 6(12) Climate Law 21; Charlotte Streck and others, 'Paris Agreement - A New Beginning' 13(1) (2016) Journal of European Environmental and Planning Law 3; Lavanya Rajamani and Emmanuel Guerin, 'Central Concepts in the Paris Agreement and How They Evolved' in Daniel Klein and others (eds), The Paris Climate Agreement: Analysis and Commentary (OUP 2017) 74; Ved Nanda and George R Pring, International Environmental Law and Policy for the 21 $1^{\text {st }}$ Century (2 ${ }^{\text {nd }}$ ed, Brill 2013); Christina Voigt, 'State Responsibility for Climate Change Damages' (2018) 77 Nordic Journal of International Law 1; Roda Verheyen, Climate Change Damage in International Law (Brill 2005); Roda Verheyen and Cathrin Zengerling, 'International Dispute Settlement' in Kevin Gray, Richard Tarasofsky and Cinnamon Carlarne (eds), The Oxford Handbook of International Climate Change Law (OUP 2016) 418; Alexander Zahar, 'The Contested Core of Climate Law' (2018) 8 Climate Law 244; Saheed Alabi, 'Using Litigation to Enforce Climate Obligations under Domestic and International Laws' (2012) 6(3) Carbon and Climate Law Review 209; Alan Boyle, 'Law of the Sea Perspectives on Climate Change' (2012) 27 The International Journal of Marine and Coastal Law 831; Meinhard Doelle, 'Climate Change and the Use of the Dispute Settlement Regime of the Law of the Sea Convention' (2006) 37(3-4) Ocean Development and International Law 319; Brian Preston, 'Climate Change Governance - The International Regime Complex' (2011) 5(2) Carbon \& Climate Law Review 244; William Burns, 'A Voice for the Fish? Litigation and Potential Causes of Action for Impacts under the United Nations Fish Stocks Agreement' (2008) 11(1) Journal of International Wildlife Law and Policy 30; Darin Bartram, 'International Litigation Over Global Climate Change: A Skeptic's View' (2007) 101 American Society of International Law 65; Benoit Mayer, 'State Responsibility and Climate Change Governance: A Light through the Storm' (2014) 13(3) Chinese Journal of International Law 539; Jacobs (n 5). 


\section{Applicants and Respondents}

This article advocates for AOSIS building on their history of success in working together in relation to climate change in order to bring a multi-party case across multiple fora. As such, Part A explains why AOSIS is a suitable group to do so. Part B then compiles a fortynine strong member Respondent Pool which it is suggested AOSIS use as a guideline when determining who all to name as respondents in the proceedings. Finally, Part $\mathrm{C}$ dispels the idea that relatively recent high emitting states should be exempted from such a Respondent Pool.

\section{A. AOSIS as Applicants}

AOSIS is composed of forty-four members ${ }^{9}$ representing $28 \%$ of developing states and $20 \%$ of UN membership. ${ }^{10}$ It is a heterogeneous collection of countries, with a range of geographical, cultural, social, and economic differences. ${ }^{11}$ The majority of members are SIDS, although not all, for example, Belize, Guyana, and Suriname. Regardless, all AOSIS members 'are at the frontline of climate change impacts, with induced existential threats'. ${ }^{12}$ More important for litigation purposes is that seven AOSIS members are not UN members nor states: American Samoa, the Cook Islands, Guam, Netherlands Antilles, Niue, Puerto Rico, United States Virgin Islands. These members are therefore precluded from ICJ proceedings, as only states may be parties in cases before the Court ${ }^{13}$ and currently the parties to the ICJ Statute are the same as those that are members of the UN. ${ }^{14}$ Their lack of statehood does not per se preclude these seven AOSIS members from proceedings under the UNCLOS. ${ }^{15}$ Indeed, the Cook Islands and Niue have ratified the UNCLOS, as well as the UNFCCC ${ }^{16}$ and the Paris Agreement, ${ }^{17}$ although the other five have not ratified any. All other AOSIS members are parties to the UNFCCC, the Paris Agreement, and the UNCLOS. Notwithstanding the jurisdictional barriers, which will be discussed in Section 4 , this leaves thirty-seven AOSIS members free to pursue litigation at the ICJ, with thirtynine free to do so under the dispute settlement procedures of the UNCLOS Part XV.

AOSIS came together in 1990 when they recognised their disproportionate vulnerability to the negative consequences of climate change. ${ }^{18}$ Island states worldwide recognised their commonality early, as well as the need to cooperate given their limited individual influence. ${ }^{19}$ Forming at the Second World Climate Conference, AOSIS was

9 Antigua and Barbuda, American Samoa, Bahamas, Barbados, Belize, Cabo Verde, Comoros, Cook Islands, Cuba, Dominica, Dominican Republic, Fiji, Federated States of Micronesia, Grenada, Guam, Guinea-Bissau, Guyana, Haiti, Jamaica, Kiribati, Maldives, Marshall Islands, Mauritius, Nauru, Netherlands Antilles, Niue, Palau, Papua New Guinea, Puerto Rico, Samoa, Singapore, Seychelles, Sao Tome and Principe, Solomon Islands, St. Kitts and Nevis, St. Lucia, St. Vincent and the Grenadines, Suriname, Timor-Leste, Tonga, Trinidad and Tobago, Tuvalu, United States Virgin Islands, Vanuatu.

10 Timothee Ourbak and Alexandre Magnan, 'The Paris Agreement and climate change negotiations: Small Islands, Big Players' 18 Regional Environmental Change (2018) 2201, 2202.

11 ibid.

12 ibid.

13 Statute of the International Court of Justice 1945 UKTS 067/1946 (ICJ Statute), art 34(1).

14 ibid; 'End Note 2' <https://treaties.un.org/Pages/ViewDetails.aspx?src=TREATY\&mtdsg_no=I$3 \&$ chapter=1\&clang=_en $>$ accessed 30 December 2020.

15 UNCLOS (n 6) art 20(2).

16 United Nations Framework Convention on Climate Change 1992 (adopted 9 May 1992, entered into force 21 March 1994) 1771 UNTS 107 (UNFCCC).

17 Paris Agreement under the United Nations Convention on Climate Change (adopted 12 December 2015, entered into force 4 November 2016) (2015) 55 ILM 743 (Paris Agreement).

18 Carola Betzold, Paula Castro and Florian Weiler, 'AOSIS in the UNFCCC negotiations: from unity to fragmentation?' 12(5) Climate Policy (2012) 591, 592.

19 ibid 593. 
among the first groups to bring the international community's attention to the dangers posed by GHG emissions, particularly the threat of sea level rise ${ }^{20}$ The group made its first formal appearance at the first meeting of the International Negotiating Committee (INC) in 1991. ${ }^{21}$ Its early work focused on getting recognition for the specific problems of SIDS and on getting the necessary representation in the negotiations. In both areas AOSIS succeeded, receiving special recognition in UNGA Resolution 45/212 (1990) and being granted access to the special fund for participation. ${ }^{22}$ AOSIS received further recognition as a severely affected group of countries, with special travel assistance being granted to SIDS to participate in INC meetings between 1992 and $1994 .{ }^{23}$ Having gained recognition as a group facing a physical threat to the survival of its member countries, an INC ViceChairman position was allocated to SIDS through an 'extra' seat, despite being 'inconsistent' with normal practice. ${ }^{24}$ AOSIS has managed to keep this position and to obtain a SIDS seat in other UNFCCC bodies, such as the Executive Board of the Clean Development Mechanism (CDM) and the boards of the Adaptation Fund and the Green Climate Fund.$^{25}$ Further reflecting the emergence of SIDS as a distinct group facing distinct challenges was the Global Conference on the Sustainable Development of SIDS in 1994 which focused specifically on the concerns of SIDS, with one of the main chapters of the program resulting from the Conference dedicated to climate change. ${ }^{26}$

Despite the relatively small size and modest demographical, economic and political weight of its members, AOSIS became one of the key players in the UNFCCC negotiations. ${ }^{27}$ They succeeded in developing 'a specific negotiating agenda addressing areas which are of overriding concern to them and succeeded in having those concerns incorporated in a legally binding Convention of historic importance [the UNFCCC]'. ${ }^{28}$ Former AOSIS negotiators Ashe, Lierop, and Cherian count the UNFCCC as a 'singular triumph' for AOSIS and highlight twelve goals that AOSIS had coming into the UNFCCC negotiations, ten of which were achieved, albeit to varying degrees. ${ }^{29}$ Of these, some of the most notable will now be briefly discussed. ${ }^{30}$

AOSIS was 'completely successful' in achieving their objective that 'the preamble should expressly recognise the particular problems and special needs of small island countries'. ${ }^{31}$ Preambular paragraph 12 recalls the provisions of the UNGA Resolutions $44 / 206$ and 44/172, both of which recognise islands and low-lying coastal areas as vulnerable to the adverse effects of sea-level rise. ${ }^{32}$ Preambular paragraph 19 recognises the vulnerability of small island countries and countries with low-lying coastal areas. Furthermore, paragraph 14 makes reference to the Ministerial Declaration of the Second World Climate Conference which refers to the special needs of small islands and low-lying

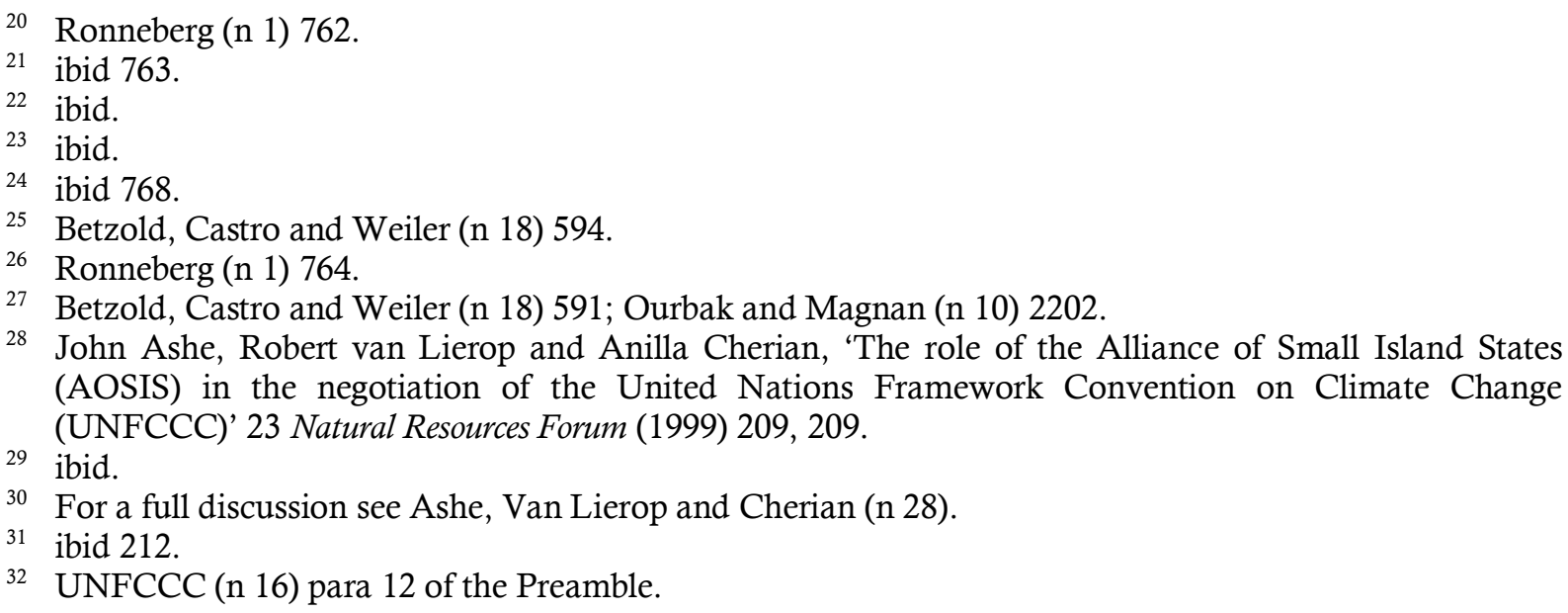


coastal states. ${ }^{33}$ AOSIS also had the objective that the special needs of small island countries should be addressed in the body of the Convention'. ${ }^{34}$ The achievement of this objective is seen in Articles 3 and 4 UNFCCC. ${ }^{35}$ Article 3(2) refers to 'the specific needs and special circumstances of developing country Parties, especially those that are particularly vulnerable to the adverse effects of climate change' ${ }^{36}$ Article 4(4) enjoins the developed country Parties to assist those countries 'which are particularly vulnerable to the adverse effects of climate change in meeting costs of adaptation to those adverse effects' ${ }^{37}$ Article 4(8) requests that full consideration be given to 'actions related to funding, insurance and the transfer of technology, to meet the specific needs and concerns of ... small island countries [and] countries with low-lying coastal areas. ${ }^{38}$ Article 4(9) asked the developed country Parties to 'take full account of the specific needs and special situations of the least developed countries', including island countries and low-lying coastal states. ${ }^{39}$ AOSIS sought for the Convention 'to establish funding mechanisms to assist developing countries to comply with the terms of the Convention' and that 'in the dispersal of monies ... priority should be given to the low-lying, coastal and small vulnerable island countries'. ${ }^{40}$ Further, that funding 'must also be applied to compensate Developing Countries for foregoing development opportunities by performing critical actions in the fight against climate change, such as preserving vital sinks for [GHGs] and adopting appropriate technologies' ${ }^{41}$ Here, the UNFCCC 'goes significantly beyond what AOSIS could reasonably have expected to achieve' ${ }^{42}$ The UNFCCC establishes a funding mechanism ${ }^{43}$ which is to meet the 'agreed full costs' relating to the implementation by developing country Parties to the Convention ${ }^{44}$ and provide for the costs of adaptation and mitigation. ${ }^{45}$ AOSIS was 'reasonably successful' in its objective that the 'Convention must include obligations of the Parties to transfer appropriate environmentally acceptable technologies to enable rapid, consistent and effective response to the prospect of climate change' ${ }^{46}$ Article $4(3)$ and 4(5) require the developed country Parties to either provide financial resources for the transfer of technology, or to 'take all practicable steps to promote, facilitate and finance, as appropriate, the transfer of, or access to, environmentally sound technologies and know-how to ... developing country Parties' ${ }^{47}$ Article 4(8) designates 'small island countries' for special consideration, while Article 11 specifies the financial mechanism that would fund the transfer of technology from developed to developing country Parties. ${ }^{48}$ Finally, the establishment of the Conference of the Parties and a secretariat, as well as a subsidiary body for scientific and technological advice $^{49}$ and a subsidiary body for implementation ${ }^{50}$ can be seen as 'extremely successful'

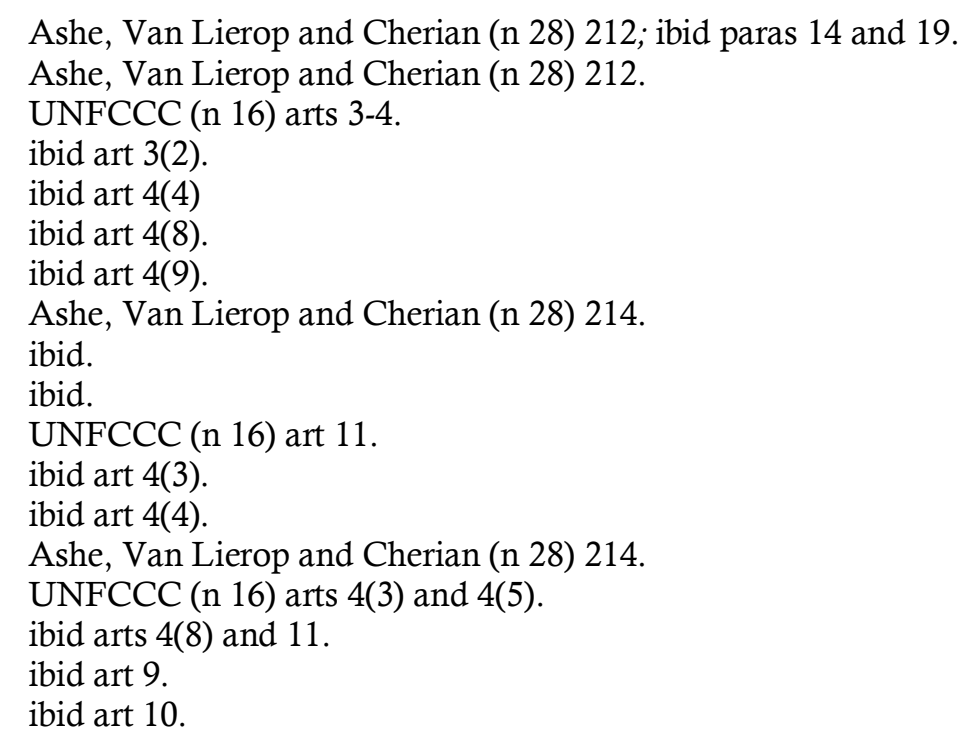


for AOSIS, who had the objective of 'existing United Nations and regional institutions working with whatever organisation bodies established by the Convention ... to implement the mandate of the Parties'. ${ }^{51}$

The Paris Agreement is considered 'a good outcome, albeit not a great one' for AOSIS. ${ }^{52}$ For the Paris negotiations, AOSIS had three main positions, of which Ourbak provides a succinct analysis. ${ }^{53}$ Firstly, they fought for the recognition of the special circumstances and needs of small islands as particularly vulnerable countries. SIDS are explicitly mentioned five times in the Paris Agreement regarding mitigation, finance, capacity building, and transparency. ${ }^{54}$ AOSIS succeeded in maintaining their special circumstances regarding flexibility in the reporting system and the new transparency framework and avoiding any additional burden in terms of reporting activities. The language related to finance in the Paris Agreement 'might be considered as a victory for SIDS, ${ }^{55}$ although they did not succeed in obtaining one of their key tasks related to the 'provisions to enhance SIDS access, especially to public, grant-based support for adaptation, given our unique challenges and the existential threat.... ${ }^{56}$ Ultimately, this represents a success for developing countries as a whole, not only SIDS. Secondly, they fought for a legally binding, ambitious agreement. AOSIS succeeded in the run up to COP21 of initiating a negotiating item called the 'structured expert dialogue' that led to a final report that mentioned the $+1.5^{\circ} \mathrm{C}$ target. Thirdly, they fought for the recognition of loss and damage. AOSIS succeeded in attaining a stand-alone article on loss and damage, although this was reduced by the decision attached to the Paris Agreement, clearly mentioning that 'Article 8 of the Agreement does not involve or provide a basis for any liability or compensation'. ${ }^{57}$ Overall, the Paris Agreement struck a delicate balance of position among all groups and countries. The final document agreed upon contained the main AOSIS positions of no 'watering down' of their status, the inclusion of the below $+1.5^{\circ} \mathrm{C}$ target as a long-term goal along with the below $+2^{\circ} \mathrm{C}$ target, and the permanence of the concept of loss and damage with a separate article.

Aside from negotiating, states within AOSIS have demonstrated their openness to pursuing litigation. During the negotiations to the UNFCCC, several SIDS joined in tabling a submission that the polluter pays principle could serve as an appropriate legal framework to address liability and compensation issues. ${ }^{58}$ When this was not acceptable to the industrialised countries, Fiji, Nauru, Papua New Guinea, and Tuvalu filed a declaration that signature 'shall in no way constitute a renunciation of any rights under international law concerning state responsibility for the adverse effects of climate change'. ${ }^{59}$ Others have gone further, with Tuvalu threatening to bring the US to the ICJ in 2002, however, this never materialised. ${ }^{60}$ In 2011, Palau considered asking the ICJ for an

51 Ashe, Van Lierop and Cherian (n 28) 214-5.

52 Ian Fry, 'The Paris Agreement: an insider's perspective - the role of Small Island Developing States' 46(2) Environmental Policy Law (2016) 105, 105.

53 Ourbak and Magnan (n 10) 2203.

54 Paris Agreement (n 17) arts 4(6), 9(4), 9(9), 11(1), 13(3).

55 Darren Hoad, 'The 2015 Paris Climate Agreement: outcomes and their impacts on small island states' 11(1) Island Studies Journal (2016) 315, 318.

56 Ourbak and Magnan (n 10) 2205.

57 UNFCCC, 'Report of the Conference of the Parties on its twenty-first session, held in Paris from 30 November to 13 December 2015' (Adoption of the Paris Agreement) FCCC/CP/2015/10/Add.1 $<$ https://unfccc.int/process/the-convention/status-of-ratification/declarations-by-parties $>$ accessed 30 December 2020.

58 Ronneberg (n 1) 773.

59 Paris Agreement (n 17).

60 Jacobs (n 5). 
Advisory Opinion on whether countries have a legal responsibility to ensure that any activities on their territory that emit GHGs do not harm other states, although again, this was not followed through. ${ }^{61}$ More recently, Vanuatu has announced that it is 'exploring all avenues' for climate litigation. ${ }^{62}$

Due to the track record of AOSIS' success, this article advocates for continued cooperation amongst SIDS when it comes to climate change litigation. The severe and disproportionate effects of climate change on AOSIS members, coupled with the passion and dedication they have consistently brought to combating climate change, make the group ideal climate change litigants. In pursuing climate litigation, one of the first problems for AOSIS is identifying suitable respondents.

\section{B. Respondents}

This Section does not attempt to provide a definitive or exhaustive list of respondents. Rather, it suggests a method for selecting respondents that balances both the competing complex considerations and concerns in making such a selection and provides a sound legal basis for doing so. The outcome is a Respondent Pool from which AOSIS could then compile a definitive list at their own discretion.

The starting point for constructing the Respondent Pool is the UNFCCC and its Annexes. Under Article 3(1) UNFCCC, it is the 'developed country Parties that should take the lead in combating climate change and the adverse effects thereof' ${ }^{63}$ Further, Article 4(1) imposes specific mitigation obligations on 'developed country Parties and other Parties included in Annex I', while Article 4(1) places adaptation obligations on 'the developed country parties and other developed Parties in Annex II' ${ }^{64}$ The latter group is also given financial obligations in relation to both mitigation and adaptation. ${ }^{65}$ From this basis comes a Respondent Pool compiled from Annex I of forty-two states and the European Union (EU), listed in Table 1 below.

61 'Palau seeks UN World Court opinion on damage caused by greenhouse gases' (n 5).

${ }^{62} \operatorname{Cox}(\mathrm{n} 5)$.

${ }^{63} \mathrm{UNFCCC}$ (n 16) art 3(1).

64 ibid arts 4(1) and 4(4).

65 ibid arts 4(3) and 4(4). 
Table 1

UNFCCC Annex I Countries (*also Annex II Countries)

$\begin{array}{lll}\text { Australia* } & \text { Hungary } & \text { Portugal* } \\ \text { Austria* } & \text { Iceland* } & \text { Romania } \\ \text { Belarus } & \text { Ireland* }^{*} & \text { Russia } \\ \text { Belgium* } & \text { Italy* } & \text { Slovakia } \\ \text { Bulgaria } & \text { Japan* } & \text { Slovenia } \\ \text { Canada* } & \text { Latvia } & \text { Spain* } \\ \text { Croatia } & \text { Liechtenstein } & \text { Sweden* } \\ \text { Cyprus } & \text { Lithuania } & \text { Switzerland* } \\ \text { Czech Republic } & \text { Luxembourg* } & \text { Turkey* } \\ \text { Denmark* } & \text { Malta } & \text { Ukraine } \\ \text { Estonia } & \text { Monaco } & \text { UK* } \\ \text { EU* } & \text { Netherlands* } & \text { USA* } \\ \text { Finland* } & \text { New Zealand* } & \text { Germany* } \\ \text { France* } & \text { Norway } & \\ \text { Greece } & \text { Poland } & \end{array}$

The obligations under the UNFCCC have been extended in the Paris Agreement, with mitigation and adaptation obligations now addressed to 'Each Party' and financial obligations extended to developed country Parties. ${ }^{66}$ Thus, all members of the Respondent Pool compiled from Annex I can be held accountable regarding mitigation, adaptation, and financial obligations in relation to both.

A Respondent Pool based solely on the UNFCCC Annexes leaves out a number of high emitting non-annex states. However, the Paris Agreement is to be 'implemented to reflect equity and the principle of common but differentiated responsibilities and respective capabilities, in the light of different national circumstances' ${ }^{67}$ This qualification represents a political signal of flexibility and dynamism. ${ }^{68}$ As national circumstances evolve, so too will the common but differentiated responsibilities of the states. This idea permeates throughout the Paris Agreement and allows for an extension of the Respondent Pool beyond the confines of the UNFCCC's annex system. If the annexes were indeed sacrosanct, as argued by non-Annex I parties, then such states would escape inclusion in a Respondent Pool regardless of their contributions to climate change and any changes in their 'national circumstances'. However, the qualification of 'national circumstances' limits the ability of states to continue to hide behind the annexes and evade culpability. ${ }^{69}$

The most notable excluded high emitting states are China, India, Brazil, Indonesia, Iran and Mexico. As seen in Table 2 and Table 3 below, not only are these states amongst the largest post-1990 emitters, but their position as high GHG emitters, relative to other states, has been significant from the start of the $20^{\text {th }}$ century and, in the case of India, Indonesia, and Mexico, the beginning of their significant levels of emissions pre-date the turn of the $20^{\text {th }}$ century. ${ }^{70}$

66 Paris Agreement (n 17) arts 4(2), 7(1), 7(6), 7(9).

67 ibid art 2(2).

68 Bodansky (n 8) 221; Rajamani and Guerin (n 8) 84.

69 Bodansky (n 8) 123; Rajamani and Guerin (n 8) 83.

70 World Resources Institute, 'CAIT Climate Data Explorer' <https://www.wri.org/ourwork/project/cait-climate-data-explorer> accessed 30 December 2020. 
Table 2

World Ranking: Cumulative GHG Emissions up to $2014^{71}$

$$
2014 \text { only } \quad 1990-2014
$$

$\begin{array}{lccc}\text { China } & 1^{\text {st }} & 1^{\text {st }} & 2^{\text {nd }} \\ \text { India } & 3^{\text {rd }} & 4^{\text {th }} & 7^{\text {th }} \\ \text { Brazil } & 6^{\text {th }} & 7^{\text {th }} & 19^{\text {th }} \\ \text { Indonesia } & 8^{\text {th }} & 11^{\text {th }} & 24^{\text {th }} \\ \text { Iran } & 10^{\text {th }} & 15^{\text {th }} & 17^{\text {th }} \\ \text { Mexico } & 11^{\text {th }} & 10^{\text {th }} & 13^{\text {th }}\end{array}$

\section{Table 3}

World Ranking: Cumulative GHG Emissions pre-199072

$\begin{array}{llll}\text { China } & 1850-1990 & 1850-1950 & 1850-1900 \\ \text { India } & 5^{\text {th }} & 12^{\text {th }} & \text { Outside Top 50 } \\ \text { Brazil } & 12^{\text {th }} & 10^{\text {th }} & 18^{\text {th }} \\ \text { Indonesia } & 22^{\text {nd }} & 34^{\text {th }} & \text { Outside Top 50 } \\ \text { Iran } & 33^{\text {rd }} & 27^{\text {th }} & 34^{\text {th }} \\ \text { Mexico } & 24^{\text {th }} & 21^{\text {st }} & \text { Outside Top 50 }\end{array}$

While these states' high levels of emissions make them attractive additions to the Respondent Pool, the precise obligation of 'Each Party' rests also upon their national circumstances. None of these six non-annex states have relatively low GDPs, the lowest being Iran, which is still the world's $28^{\text {th }}$ largest economy. ${ }^{73}$ On the contrary, China is the world's second largest economy, India and Brazil are in the top 10, and Mexico and Indonesia are in the top $20 .{ }^{74}$ However, each has a GDP per capita of below US $\$ 10,000^{75}$ and while China, Brazil, Mexico and Iran are classified by the World Bank as upper-

71 The World Bank, 'GDP' <https://data.worldbank.org/indicator/ny.gdp.mktp.cd?view=map > accessed 30 December 2020.

72 ibid.

73 The World Bank, 'GDP per capita' <https://data.worldbank.org/indicator/ny.gdp.pcap.cd> accessed 30 December 2020.

74 The World Bank, 'World Bank Country and Lending Groups' available at <https://datahelpdesk.worldbank.org/knowledgebase/articles/906519-world-bank-country-andlending-groups $>$ accessed 30 December 2020.

75 The World Bank, 'GDP per capita' <https://data.worldbank.org/indicator/ny.gdp.pcap.cd>accessed 30 December 2020. 
middle-income economies, India and Indonesia are lower-middle-income economies. ${ }^{76}$ While there are several competing national circumstances to take into consideration, 'Each Party' nonetheless has at least some adaptation and mitigation obligations, while whether they also have financial obligations is dependent upon their status as a developed or developing nation. Further, being at the bottom of the chain when it comes to climate change, AOSIS are unlikely to be deterred from bringing a case against these non-Annex countries and may even wish to expand their net wider. Therefore, China, India, Brazil, Mexico, Indonesia, and Iran are added to the Respondent Pool for consideration by AOSIS. This brings the Respondent Pool to forty-nine members: forty-eight states plus the EU.

\section{The Historical Argument Debunked}

Relatively recent high emitting states such as China, India, Brazil, Mexico, Indonesia, and Iran typically raise the historical emissions argument when attempting to deny culpability and escape liability for their emissions. The argument for exemption rests upon the assumption that liability for GHG emissions should be determined on a strict basis, rather than a negligence approach. ${ }^{77}$ A strict liability approach would take into account all historical emissions. That the existing level of climate change is arguably predominantly caused by decades-old emissions, dating back to the industrial revolution, raises the question of whether it is reasonable to hold more recent large emitters accountable for the damage that they have contributed relatively very little to. On the other hand, a negligence approach to liability would make states responsible only for GHG emissions 'since sometime between the early 1960s and the early 1990s, when a scientific consensus grew on the occurrence of climate change and on its anthropogenic causes' ${ }^{78}$ The question then becomes whether it is reasonable to hold historically high emitters accountable for damages that they did not reasonably foresee. The Seabed Disputes Chamber of ITLOS in its Advisory Opinion on Responsibilities in the Area stated that the due diligence standard required from states 'may change over time as measures considered sufficiently diligent at a certain moment may become not diligent enough in light, for instance, of new scientific or technological knowledge. It may also change in relation to the risks involved in the activity ... [and] be more severe for the riskier activities'.$^{79}$ Thus, it can be asserted that the standard of care had increased by 1992 with the adoption of the UNFCCC. It could be argued that the increased standard could be applied earlier, either from 1990 with the first IPCC assessment report, 1988 with the UN General Assembly Resolution on climate change, or even 1979 with the First World Climate Conference. It can be further asserted that this standard has been periodically increasing, in light of new scientific and technological knowledge, which is most authoritatively contained in IPCC reports, and recognised by the international community through a succession of climate change negotiations, the most recent and important result of which is the Paris Agreement. Finally, again drawing upon Responsibilities in the Area, it could be asserted that, while not determining the exact substance of the standard, the now well-known 'risks' of GHG

76 The World Bank, 'World Bank Country and Lending Groups' available at <https://datahelpdesk.worldbank.org/knowledgebase/articles/906519-world-bank-country-andlending-groups $>$ accessed 30 December 2020.

77 See Benoit Mayer (n 8).

78 ibid 554.

79 Responsibilities and Obligations of States Sponsoring Person and Entities with Respect to Activities in the Area (Advisory Opinion) [2011] ITLOS Reports 2011, paras 115 and 117. 
emitting activities warrant the standard being 'severe', and that this move towards greater severity also increased in step with new scientific and technological knowledge.

\section{Conclusion}

This Section has highlighted AOSIS' suitability as applicants in climate change litigation. The Section then provided a Respondent Pool of 49 members, 48 states and the EU, from which it is suggested that respondents are selected. The basis of the Respondent Pool was built upon the UNFCCC Annexes, before both the obligations of each member and the scope of the membership were expanded in light of the Paris Agreement. Finally, the Section showed that non-annex states could not escape inclusion in the Respondent Pool by hiding behind the historical emissions argument. Having identified both applicants and respondents, Section 3 now showcases the inventories of legal bases that AOSIS could invoke in proceedings between the groups.

\section{Inventory of Legal Bases}

In order to overcome the jurisdictional barriers posed by international litigation, a variety of legal bases must be utilised before multiple international bodies. This Section briefly inventories these legal bases, providing context for the legal proceedings before each body, and for Section 4 which lays out how the jurisdictional barriers of each body can be overcome, completing the Blueprint for the first international multi-party climate change case.

\section{A. Climate Change Treaty Law}

The UNFCCC ${ }^{80}$ established the governance structure for the international climate regime, and, after more than two decades, it remains the foundation of the regime. ${ }^{81}$ The Paris Agreement, ${ }^{82}$ 'a monumental triumph' ${ }^{\prime 3}$ is the latest development and lays down a framework for the management of climate change from 2020 onwards. While the Paris Agreement establishes a new regime for the future management of climate change, it rests on the foundations of, and is intended to extend, the provisions of the UNFCCC. ${ }^{84}$ The regime lays down mitigation and adaptation commitments as well as financial commitments related to both. A court or tribunal could rule that states are legally required to do more to meet these commitments and fulfil the objective of the regime. ${ }^{85}$

While the Paris Agreement has 186 ratifications, notable exceptions include Russia, Turkey, and Iran, which are all included in the Respondent Pool. States not party to the Paris Agreement do not of course fall outside the reach of customary international law.

\section{B. Customary International Law}

The no-harm rule is 'the most basic prescriptive rule and the backbone of international environmental law ${ }^{\prime 86}$ and the most important customary law rule in the context of climate

\footnotetext{
$80 \mathrm{UNFCCC}$ (n 16).

81 Bodansky (n 8) 118.

82 Paris Agreement (n 17).

83 'COP21: UN Chief hails new climate change agreement as "monumental triumph"' (UN News, 12 December 2015) <http://www.un.org/apps/news/story.asp?NewsID=52802\#.Vrh45fl96Uk> accessed 30 December 2020.

84 Philipe Sands, Principles of International Environmental Law (2nd edn, 2003) 300.

85 See Horn (n 8) 177; Jacobs (n 5) 112; Elborough (n 8) 96; Wilder (n 8); Bodansky (n 8); Mace (n 8); Streck (n 8); Rajamani and Guerin (n 8).

86 Nanda and Pring (n 8) 23.
} 
change. ${ }^{87}$ AOSIS could base an argument on the no-harm rule and claim compensation for damages resulting from violations of the rule. ${ }^{88}$ They could also ask a court or tribunal to rule that states must do more in order to comply with the rule, and further, that current efforts are not sufficient. Such arguments would most naturally be invoked before the ICJ and, as explained later in Section 4, only nine AOSIS members and thirty-three Respondent Pool states are Parties to the ICJ Statute, and so only these states could be directly involved in ICJ proceedings. This notably excludes the US and China, as well as Russia, Turkey, and Iran, which are still seemingly out of the law's reach. Those states not parties to the ICJ Statute can however be brought into proceedings through the utilisation of the law of the sea regime.

\section{Law of the Sea}

The law of the sea, governed by UNCLOS, provides another legal regime that could be utilised by AOSIS and, when used in conjunction with the climate change treaty regime and the no-harm rule, ensures that all AOSIS members can be involved in proceedings. AOSIS can base an argument on UNCLOS that through their GHG emissions, states are polluting the marine environment.$^{89}$ Additionally, an argument can be made under the Fish Stocks Agreement that such pollution is adversely affecting the conservation and sustainable use of fish stocks. ${ }^{90}$ The Fish Stocks Agreement offers the unique advantage of being able to bring a case directly against the US and Iran, as it applies the UNCLOS dispute resolution mechanism to any dispute under the Fish Stocks Agreement, even where one or more of the disputants are not Parties to UNCLOS. ${ }^{91}$ Indeed, while offering a further legal argument, the utilisation of the Fish Stocks Agreement is mainly to ensure that these states, especially the US, can definitely be subject to litigation proceedings. China and Russia are also caught in the law of the sea net; however, Turkey remains the sole outlier.

\section{Conclusion}

By invoking a range of legal bases, all AOSIS member states are afforded the opportunity of being involved in proceedings. From the Respondent Pool, all but Turkey are captured. Section 4 now discusses the jurisdictional issues that would be involved and shows how they can be overcome, potentially even bringing Turkey into proceedings.

\section{Forum and Jurisdiction}

Having identified possible legal arguments and the applicants and respondents, the next step in successful climate litigation is overcoming the jurisdiction barriers and actually having the case heard before a court or tribunal. This Section shows that it is in fact possible to overcome these barriers so that the AOSIS members can bring proceedings against the

87 Voigt (n 8) 7.

88 For support of the no-harm rule in climate litigation see Verheyen (n 8) 225; Verheyen and Zengerling (n 8) 428; Voigt (n 8) 7-9; Bodansky (n 8) 44; Mayer (n 8) 552-4. For a rebuke of the applicability of the noharm rule to climate change litigation see Zahar (n 8) 244.

89 See Alabi (n 8); Boyle (n 8); Doelle (n 8); Jacobs (n 5) 116-117; Horn (n 8) 182-184.

90 Preston (n 8) 260; Burns (n 8) 9; Verheyen and Zengerling (n 8) 430. For a critique of the use of these socalled 'strained' legal bases see Bartram (n 8).

91 Agreement for the Implementation of the Provision of the United Nations Convention on the Law of the Sea of 10 December 1982 relating to the Conservation and Management of Straddling Fish Stocks and Highly Migratory Fish Stocks (adopted 4 December 1995, entered into force 11 December 2001) 2167 UNTS 3 (Fish Stocks Agreement), art 30(1). 
full Respondent Pool. To do so, the ICJ, ITLOS, and arbitral tribunals will all need to be utilised. Solutions for overcoming the jurisdictional barriers these bodies present are therefore offered: through forum prorogatum with regard to respondents, and intervention with regard to applicants.

Part A first addresses the jurisdictional issues faced by AOSIS member states in bringing a case before the ICJ. The ICJ poses jurisdictional problems to AOSIS on both the applicant and respondent side, especially as top-emitting states such as the US and China have not consented to the jurisdiction of the Court. Although Vanuatu is the most recent AOSIS member to make public its intention to litigate, even it would be unable to go before the ICJ alone for the same reason. However, it will be seen that together AOSIS can overcome such obstacles.

Part B outlines how the dispute settlement procedure under UNCLOS Part XV can be utilised to ensure that all AOSIS Members are able to bring a case against the full Respondent Pool. Under UNCLOS, the litigation strategy entails procedures before both ITLOS and an Annex VII arbitral tribunal, or an Annex VIII special arbitral tribunal, and so Part B discusses the jurisdictional procedures in seizing each of these bodies. The Section outlines how those AOSIS members unable to directly bring a case before the ICJ can bring one before ITLOS, and in turn, those unable to seize even ITLOS, can seize an Annex VII tribunal, with Annex VIII also being available.

\section{A. The ICJ}

\section{i. Jurisdiction}

As the principal judicial organ of the $\mathrm{UN},{ }^{92}$ the ICJ could play a central role in facilitating and directing necessary action by states. Achieving a favourable decision at the ICJ would be a significant victory for AOSIS, providing immediate relief as well as 'an authoritatively sanctioned reference point around which public opinion can crystallize ${ }^{\prime 93}$ and that resonates through international society. ${ }^{94}$ Nevertheless, decisions of the Court are only binding 'between the parties and in respect of that particular case'. ${ }^{95}$ This is significant to climate litigation, as the impact of a favourable decision greatly depends upon who the parties to the dispute are. Further, in accordance with the principle of state sovereignty, the Court only has jurisdiction over states that have consented to this. ${ }^{96}$ This presents a substantial obstacle as relatively few AOSIS members have consented to the Court's jurisdiction, while, on the respondent side, neither have a number of the Respondent Pool.

This Section discusses the ways in which jurisdiction can be conferred upon the Court, beginning with special agreements under Article 36(1) ICJ Statute, ${ }^{97}$ then treaties and compromissory clauses, and finally optional clauses under Article 36(2) ICJ Statute. ${ }^{98}$ Given the complications this presents, the potential of the multi-party litigation strategy advocated by this article in overcoming jurisdictional obstacles is then examined.

92 Charter of the United Nations (adopted 26 June 1945, entered into force 24 October 1945) 1 UNTS XVI (UN Charter), art 92.

93 Andrew Strauss, 'Climate Change Litigation: Opening the Door to the International Court of Justice' in William Burns and Hari Osofsky (eds), Adjudicating Climate Change: State, National and International Approaches (2009) 334, 337.

94 Gleider Hernandez, The International Court of Justice and the Judicial Function (2014) 5.

95 ICJ Statute (n 13) art 59.

96 ibid art 36.

97 ibid art 36(1).

98 ibid art 36(2). 


\section{a. Conferring jurisdiction}

\section{Special Agreement}

The simplest way to confer jurisdiction is for the parties to enter into an agreement to that effect. This method of 'special agreement' is one of the two methods mentioned in Article 36(1) ICJ Statute. ${ }^{99}$ Such an agreement will define the dispute, usually record that the decision of the Court will be accepted as binding, and may indicate applicable law. ${ }^{100}$ There are unlikely to be jurisdictional problems as the consent of the parties is clear and obvious, given they have concluded a treaty specifically to confer jurisdiction for a specific case.

While, in theory, jurisdiction conferred via special agreement may be the simplest method, with little danger of jurisdictional problems, it is unlikely that AOSIS members could persuade states to agree to conclude such an agreement. ${ }^{101}$ Thus, other methods must be analysed.

\section{Treaties and compromissory clauses}

A treaty may be concluded providing for future disputes to be submitted to the Court. This may be a general treaty on the settlement of disputes contemplating a role for the ICJ, of which there are three: the General Act for the Pacific Settlement of International Disputes, ${ }^{102}$ the American Treaty on Pacific Settlement, ${ }^{103}$ and the European Convention for the Peaceful Settlement of Disputes. ${ }^{104}$ The General Act has only eight parties, none of which are AOSIS members, and the regional scope of the European Convention deems it inapplicable for use by AOSIS. The American Treaty on Pacific Settlement is slightly more useful, with the Dominican Republic, Haiti, Brazil and Mexico being Parties. ${ }^{105}$ Thus, the Dominican Republic and Haiti could choose to bring a case against Brazil and Mexico before the ICJ by virtue of the American Treaty on Pacific Settlement. ${ }^{106}$ As discussed in the following Section and shown in Table 4, the Dominican Republic, Haiti, and Mexico are Parties to the ICJ Statute anyway and so the American Treaty on Pacific Settlement is therefore made somewhat redundant. However, it could still be used to include Brazil in any ICJ proceedings, although only so far as they relate to proceedings between the Dominican Republic, Haiti and Brazil.

A compromissory clause may be inserted into a treaty providing for any dispute on the interpretation or application of the treaty to be referred, under certain conditions, to the ICJ ${ }^{107}$ Of particular relevance is Article 14(2) UNFCCC which provides for the possibility of states to recognise 'as compulsory ipso facto, and without special agreement' the submission to the Court of disputes 'concerning the interpretation or application of the

\footnotetext{
99 ibid art 40(1).

${ }^{100}$ Hugh Thirlway, The International Court of Justice (2016) 43; Robert Kolb, The Elgar companion to the International Court of Justice (2014) 197.

${ }^{101}$ Strauss (n 93) 340.

102 Revised General Act for the Pacific Settlement of International Disputes (adopted 28 April 1949, entered into force 20 September 1950) 71 UNTS 101.

${ }^{103}$ American Treaty on Pacific Settlement (adopted 30 April 1948, entered into force 6 May 1949) 30 UTS 55.

104 European Convention for the Peaceful Settlement of Disputes (adopted 29 April 1957, entered into force 30 April 1958) 329 UNTS 243.

${ }^{105}$ American Treaty on Pacific Settlement (n 101); Signatories and Ratifications are available at <http://www.oas.org/juridico/english/Sigs/a-42.html> accessed 30 December 2020.

106 ibid art XXXI.

${ }^{107} \mathrm{Kolb}$ (n 100) 188.
} 
Convention'. ${ }^{108}$ Article 24 Paris Agreement states that Article 14 UNFCCC 'shall apply mutatis mutandis' to the Paris Agreement. ${ }^{109}$ Submission of a case to the Court is only one of two options provided for by Article 14(2), the other being arbitration, which must be selected by way of a written declaration and has effect only in relation to any Party accepting the same obligation'. ${ }^{110}$ Article 14(2) has never been used, and the Netherlands is the only state that has submitted a declaration recognising the Court as compulsory. ${ }^{111}$ Thus, AOSIS members are unable to utilise the compromissory clause in bringing a case.

\section{The Optional Clause System}

Under Article 36(2) ICJ Statute, a State may deposit with the UN Secretary-General a declaration that it accepts the jurisdiction of the Court. ${ }^{112}$ Article 36(5) ICJ Statute preserves any declarations made under the PCIJ Statute. ${ }^{113}$ This method of acceptance of jurisdiction is made in advance of, and unrelated to, any disputes arising. Such declarations are regarded as unilateral acts, as whether a declaration is made at all, and if so upon what terms, is solely a matter of the will of the declarant state. ${ }^{114}$ However, due to the reciprocity principle, they necessarily become bilateral in their operation. ${ }^{115}$ This is contemplated by the phrase 'in relation to any other State accepting the same obligation'. ${ }^{116}$ The Court, in Military and Paramilitary Activities in and against Nicaragua, described how this operates in practice, explaining that, once an optional clause declaration has been submitted the coincidence or interrelation of those obligations thus remain in a state of flux until the moment of the filing of an application instituting proceedings. ${ }^{117}$ The Court has then to ascertain whether, at that moment, the two states accepted 'the same obligation' in relation to the subject matter of the proceedings' ${ }^{118}$ The optional clause system creates, as far as possible, a system of compulsory jurisdiction, where each state can unilaterally bring before the Court a claim against another state. ${ }^{119}$ This compulsory jurisdiction is not established among all state parties to the ICJ Statute by virtue of ratification, but only among those state parties that have issued an optional declaration.

Only seventy-three states have made optional declarations. ${ }^{120}$ The lack of favour in the mechanism brings difficulties for AOSIS. From the Respondent Pool, Belarus, Brazil, China, Croatia, Czech Republic, France, Iceland, Indonesia, Iran, Latvia, Russia, Slovenia, Turkey, Ukraine, and the US have not submitted optional declarations, while the EU is inapplicable in this regard. The other thirty-three members of the Respondent

${ }^{108}$ UNFCCC (n 16) art 14(2).

109 Paris Agreement (n 17) art 24.

${ }^{110}$ UNFCCC (n 16) art 14(2).

111 Verheyen and Zengerling (n 8); See also UNFCC, 'Declarations by Parties' $<$ https://unfccc.int/process/the-convention/status-of-ratification/declarations-by-parties $>$ accessed 30 December 2020.

${ }_{112}$ ICJ Statute (n 13) art 36(2).

113 ibid art 36(5).

114 Thirlway (n 100) 46; Kolb (n 98) 189.

${ }^{115}$ Vanda Lamm, 'The Legal Character of the Optional Clause System' 42 Acta Juridica Hungarica (2001) $25,33$.

116 Thirlway (n 100) 46; ICJ Statute (n 13) art 36(2). Case concerning military and paramilitary activities in and against Nicaragua (Nicaragua $v$ United States of America) (Jurisdiction and Admissibility) [1984] ICJ Rep 392 (Nicaragua).

118 ibid para 64.

119 Malgosia Fitzmaurice, 'The Optional Clause system and the law of treaties: issues of interpretation in recent jurisprudence of the International Court of Justice' 20 Australian Yearbook of International Law (1990) 127, 130; Kolb (n 100) 190.

${ }^{120}$ See list of declarations recognizing the jurisdiction of the International Court of Justice as compulsory, available at <https://www.icj-cij.org/en/declarations> accessed 30 December 2020. 
Pool have submitted declarations. ${ }^{121}$ On the applicants' side, only nine AOSIS members have submitted optional clause declarations. While the other members 'may at any time' submit a declaration, it is common for states to attach to their declarations the qualification that they do not consent to the Court's jurisdiction in regard to disputes in respect of which another Party has accepted jurisdiction only in relation to or for the purpose of the dispute, or where the declaration was deposited less than twelve months prior to the filing of the application bringing the dispute before the Court. Indeed, a number of Respondent Pool members have such a reservation qualifying their acceptance of jurisdiction. ${ }^{122}$ Thus, if other AOSIS members were to submit an optional clause declaration, it would at best delay proceedings by another year and even then would probably not allow them to take part in proceedings as it would be easy to assert that they have submitted the declarations for the purpose of the climate change dispute.

On the face of it, it would appear that only nine AOSIS members could bring a case against the thirty-three members of the Respondent Pool that have submitted declarations. Brazil could also be added if the Dominican Republic and or Haiti choose to utilise the American Treaty on Pacific Settlement. The states involved are shown in Table $4 .{ }^{123}$ However, on the applicant side, other AOSIS members may be able to join the proceedings through intervention, while on the respondent side, it can be attempted to bring states into the proceedings by virtue of forum prorogatum. Both of these will be discussed in detail, but before doing so, the complications resulting from the possibility of attaching reservations to optional clause declarations must be addressed.

\section{Table 4}

\begin{tabular}{|c|c|c|c|c|}
\hline AOSIS & \multicolumn{2}{|c|}{ Respondent Pool } & & \\
\hline Barbados & Australia & Germany & Luxembourg & Romania \\
\hline Dominica & Austria & Greece & Malta & Slovakia \\
\hline Dominican Republic & Belgium & Hungary & Mexico & Spain \\
\hline Guinea-Bissau & Bulgaria & India & Monaco & Sweden \\
\hline Haiti & Canada & Ireland & Netherlands & Switzerland \\
\hline $\begin{array}{c}\text { Marshall Islands } \\
\text { Mauritius } \\
\text { Suriname } \\
\text { Timor-Leste }\end{array}$ & $\begin{array}{l}\text { Cyprus } \\
\text { Denmark } \\
\text { Estonia } \\
\text { Finland }\end{array}$ & $\begin{array}{l}\text { Italy } \\
\text { Japan } \\
\text { Liechtenstein } \\
\text { Lithuania }\end{array}$ & $\begin{array}{l}\text { New Zealand } \\
\text { Norway } \\
\text { Poland } \\
\text { Portugal }\end{array}$ & $\begin{array}{l}\mathrm{UK} \\
\text { Brazil (only in } \\
\text { relation to the } \\
\text { Dominican } \\
\text { Republic and/or } \\
\text { Haiti) }\end{array}$ \\
\hline
\end{tabular}

${ }^{121}$ See declarations of Australia, Austria, Belgium, Bulgaria, Canada, Croatia, Cyprus, Denmark, Estonia, Finland, Germany, Greece, Hungary, Ireland, Italy, Japan, Liechtenstein, Lithuania, Luxembourg, Malta, Monaco, Netherlands, New Zealand, Norway, Poland, Portugal, Romania, Slovakia, Spain, Sweden, Switzerland, UK.

${ }^{122}$ See Declarations recognising the jurisdiction of the Court as compulsory: Australia, Bulgaria, Germany, Greece, Hungary, India, Italy, Japan, Lithuania, Malta, New Zealand, Poland, Portugal, Romania, Slovakia, Spain, UK <https://www.icj-cij.org/en/declarations> accessed 30 December 2020.

${ }^{123}$ Remaining States are Australia, Japan, Belgium, Canada, Denmark, Finland, Germany, Greece, Ireland, Italy, Japan, Luxembourg, Netherlands, New Zealand, Norway, Portugal, Spain, Sweden, Switzerland, and the UK. 


\section{Reservations to Optional Clauses}

Not only is consent to the Court's jurisdiction under Article 36 ICJ Statute an entirely voluntary act, but a state is also absolutely free to specify the limits of its consent. ${ }^{124}$ Article 36(3) provides for the possibility of making an optional clause declaration either 'unconditionally', or with reservations attached. ${ }^{125}$ Specifically, the reservations foreseen were 'a condition of reciprocity on the part of several or certain states' and acceptance 'for a certain time'. ${ }^{126}$ The content of reservations is not limited by Article 36(3), which has never been regarded as laying down an exhaustive list. ${ }^{127}$ There are a number of potentially problematic reservations for AOSIS.

Firstly, a common reservation that numerous Respondent Pool members have is one which excludes jurisdiction in cases where the parties have agreed to settle disputes by other means of peaceful settlement. Article 14 UNFCCC, which, by virtue of Article 24 Paris Agreement 'shall apply mutatis mutandis' to the Paris Agreement, could be interpreted as constituting other means of peaceful settlement. ${ }^{128}$ Article 14(1) UNFCCC provides that parties can jointly seek settlement of their dispute 'through negotiation or any other peaceful means of their own choice'. ${ }^{129}$ Article 14(2) provides that Parties can submit declarations recognising the compulsory jurisdiction of either the ICJ or arbitration. ${ }^{130}$ If the parties have failed to settle their dispute through the methods mentioned in Article 14(1), or subject to declarations made under Article 14(2), then the dispute shall be submitted, at the request of any of the parties to the dispute, to conciliation. ${ }^{131}$

The fact that states have not submitted a declaration under Article 14(2) granting the ICJ jurisdiction should not preclude the Court adjudicating climate claims pursuant to their declarations made under Article 36 ICJ Statute as states only need to consent to the Court's jurisdiction once. ${ }^{132}$ Moreover, that only the Netherlands has accepted the ICJ's jurisdiction by way of an Article 14(2) UNFCCC declaration, and that neither the procedures for arbitration nor conciliation envisaged by the Article have ever been carried out by the parties, could be interpreted as meaning that there is no final agreement providing for another means of peaceful settlement under the parties Article 36(3) ICJ Statute reservations. ${ }^{133}$ In addition, opting into ICJ jurisdiction under Article 36 ICJ Statute could be argued to make ICJ dispute settlement an 'other peaceful means of [the Parties'] own choice' under Article 14(1) UNFCCC and so to have also opted in under Article 14(2) UNFCCC would have been redundant. ${ }^{134}$ An argument could therefore be made by AOSIS members that the ICJ has jurisdiction over a climate case despite the existence of Article 14 UNFCCC.

Other problematic reservations are Poland, Romania, and Slovakia's which exclude disputes regarding environmental protection. ${ }^{135}$ Arguably this could prevent them being respondents in a climate change case before the ICJ. Bulgaria excludes 'disputes arising under [UNCLOS] or any other multilateral or bilateral agreement on the law of the sea, or

${ }^{124}$ Fitzmaurice (n 119) 131.

${ }^{125}$ ICJ Statute (n 13) art 36(5).

126 ibid.

127 Aerial Incident of 10 August 1999 (Pakistan v India) ICJ Rep 12 (2000), para 37.

${ }^{128}$ UNFCCC (n 16) art 14; Paris Agreement (n 17) art 24.

${ }^{129}$ UNFCCC (n 16) art 14(1).

130 ibid art $14(2)$.

131 ibid art 14(5).

${ }_{132}^{132}$ ICJ Statute (n 13) art 36(2)(a).

${ }^{133}$ Strauss (n 93) 343; Verheyen and Zengerling (n 8) 420; Boyle (n 8) 837-838; Elborough (n 8) 96.

134 ibid.

${ }^{135}$ Declarations recognising the jurisdiction of the Court as compulsory, available at $<$ https://www.icjcij.org/en/declarations> accessed 30 December 2020. 
customary international law on the sea, including but not limited to disputes concerning ... protection and preservation of the marine environment'. ${ }^{136}$ Similarly, Norway's reservation states that the 'limitations and exceptions relating to the settlement of disputes pursuant to the provisions of, and the Norwegian declarations applicable at any given time to ... [UNCLOS] and the [Fish Stocks Agreement] shall apply to all disputes concerning the law of the sea'. ${ }^{137}$ Thus, arguments based on the UNCLOS may not be able to be used against Bulgaria and Norway, although customary international law and climate treaty arguments are unaffected and UNCLOS arguments can still be raised before ITLOS or an arbitral tribunal. India excludes 'disputes concerning the interpretation or application of a multilateral treaty unless all the parties to the treaty are also parties to the case before the Court or the Government of India specially agree to jurisdiction' ${ }^{138}$ This may prevent climate treaty arguments being used against India, although India leave open the possibility of nevertheless agreeing to jurisdiction and the UNCLOS and customary international law arguments are unaffected.

Ultimately, it will be for the Court to decide whether a reservation prevents a state's participation, not the respondent states themselves, and so none of the above reservations should deter AOSIS members from pursuing their cause through the ICJ. Nevertheless, one of the problems that persist is that very few AOSIS members and some of the most sought-after respondents have not submitted declarations under Article 36 ICJ Statute. However, suggestions will now be offered on how these obstacles can be overcome.

\section{b. Overcoming the obstacles to jurisdiction}

\section{Forum prorogatum}

Respondent Pool members that have not submitted an optional clause declaration may be brought into a case before the ICJ by virtue of the principle forum prorogatum. The ICJ Statue only requires an application to specify 'the subject of the dispute and the parties', while the Rules of the Court only require that it indicates 'as far as possible' the basis of jurisdiction relied on. ${ }^{139}$ Thus, AOSIS members would be permitted to make an application that invites states to consent to jurisdiction only for that specific case. It would require that they do not raise preliminary objections and act inconsistently with an intention to contest the competence of the court. ${ }^{140}$

Forum prorogatum has been used against states whose attitude to judicial settlement made it unlikely that jurisdiction would be established, the object being to gain publicity for the claim and demonstrate the applicant's desire and readiness for judicial settlement. ${ }^{141}$ An addition was made to the Rules of Court in 1978, whereby an application of this kind would be treated as ineffective until the respondent's consent was forthcoming, meaning that, until then, the application would not be circulated to the Members under Article 40(3) ICJ Statute, nor would the case be entered on the General List maintained under Article

\footnotetext{
136 ibid.

137 ibid.

138 ibid.

139 ICJ Statute (n 13) art 40; See Rules of Court (1978) <https://www.icj-cij.org/en/statute> accessed 30 December 2020; see Thirlway (n 100) 51.

$140 \mathrm{Kolb}$ (n 100) 198.

141 Thirlway (n 100) 52; Aerial Incident of 7 November 1954 (United States of America v. Union of Soviet Socialist Republics) ICJ Press Release 1959/34 <https://www.icj-cij.org/files/case-related/28/12335.pdf> accessed 30 December 2020; Antarctica (United Kingdom v. Chile) ICJ Press Release 1955/26 $<$ https://www.icj-cij.org/files/case-related/27/12325.pdf $>$ accessed 30 December 2020.
} 
36(1)(b) ICJ Statute. ${ }^{142}$ Although the new rule may have reduced the attractiveness of the approach, such applications have not disappeared completely. Equatorial Guinea brought an application against France in 2012, ${ }^{143}$ Argentina brought one against the US in 2014, ${ }^{144}$ and in the same year the Marshall Islands sought to rely on forum prorogatum in six separate applications regarding the same subject matter against China, France, Israel, North Korea, Russia, and the US. ${ }^{145}$ While in no instance have the intended respondents engaged with the request and so jurisdiction has not been established, the fact that the ICJ still issues a press release noting the fact of application means that the matter is still publicised despite the new rule and, indeed, news agencies did report it. ${ }^{146}$ In 2016, Equatorial Guinea brought a fresh application against France regarding the same subject matter, this time seeking to confer jurisdiction through various treaties and compromissory clauses. ${ }^{147}$ The case is ongoing before the ICJ and the Court has ruled on preliminary objections, confirming its jurisdiction. ${ }^{148}$

While publicity of an application by AOSIS members would certainly bring public attention to the issue, that is only a by-product of the end goal of actually bringing those states before the ICJ. There have been two instances, both against France, where such a 'naked attempt' at establishing jurisdiction has succeeded, and even the US itself has previously employed the principle. ${ }^{149}$ It is therefore not outside the realm of possibility that Respondent Pool members that have not accepted the Court's jurisdiction could nevertheless successfully be brought before the ICJ as part of a multi-party case by virtue of forum prorogatum. Climate change is currently one of the most, if not the most, reported global issues and public pressure for governments to take more action is intense and ever increasing. Further, the states would come under strong political pressure from the other listed respondents, as well public pressure from their own populations, not to shy away

${ }^{142}$ Rules of the Court (n 139) art 38(5).

${ }^{143}$ Application instituting proceedings including a request for provisional measures (Republic of Equatorial Guinea $v$ France) ICJ Press Release 2012/26 <https://www.icj-cij.org/public/files/press-releases/6/17096.pdf> accessed 30 December 2020.

144 Application of the Convention on the Prevention and Punishment of the Crime of Genocide (Croatia v. Serbia) ICJ Press Release 2014/15 <https://www.icj-cij.org/public/files/case-related/118/18258.pdf> accessed 30 December 2020.

145 Applications against nine States for their alleged failure to fulfil their obligations with respect to the cessation of the nuclear arms race at an early date and to nuclear disarmament (Republic of the Marshall Islands $v$ China and others) ICJ Press Release 2014/18 <https://www.icj-cij.org/public/files/press-releases/0/18300.pdf> accessed 30 December 2020.

146 See Reuters Staff, 'Argentina seeks legal case against U.S. in the Hague' (Reuters, 7 August 2014) $<$ https://uk.reuters.com/article/uk-argentina-debt-usa-courts-idUKKBN0G724U20140807> accessed 30 December 2020; 'Marshall Islands nuclear arms lawsuit thrown out by UN's top court' (The Guardian, 6 October 2016) <https://www.theguardian.com/world/2016/oct/06/marshall-islands-nuclear-armslawsuit-thrown-out-by-uns-top-court> accessed 30 December 2020; 'Equatorial Guinea sues France over corruption inquiry' (BBC News, 26 September 2012) <https://www.bbc.com/news/world-africa$19732360>$ accessed 30 December 2020.

147 Immunities and Criminal Proceedings (Equatorial Guinea v. France) (Application Initiating Proceedings) General List No 163 [2016] <https://www.icj-cij.org/public/files/case-related/163/163-20160613APP-01-00-EN.pdf $>$ accessed 30 December 2020.

${ }^{148}$ Immunities and Criminal Proceedings (Equatorial Guinea v. France) (Preliminary Objections) [2017] $<$ https://www.icj-cij.org/public/files/case-related/163/163-20170330-WRI-01-00-EN.pdf> accessed 30 December 2020.

149 Sienyo Yee, 'Forum Prorogatum Returns to the International Court of Justice' (2003) 16 Leiden Journal of International Law 701, 702; Certain Criminal Proceedings in France (Republic of Congo v France), Summary 2003/3 <https://www.icj-cij.org/public/files/case-related/129/8206.pdf> accessed 30 December 2020; Certain Questions of Mutual Assistance in Criminal Matters (Djibouti v France) ICJ Report [2008] 177; Aerial Incident of 7 October 1952 (United State of America v Union of Soviet Republics) ICJ Press Release 1955/31 $<$ https://www.icj-cij.org/public/files/case-related/28/12335.pdf> accessed 30 December 2020. 
and to join them in answering for and defending their position as high GHG emitters. Perhaps this coupling of public and political pressure could be enough to persuade states to accede to proceedings.

\section{Intervention}

The lack of AOSIS members who may submit an application before the ICJ may be overcome through intervention. There are two possibilities for intervention under the ICJ Statute. Firstly, Article 63 provides for a right of intervention by a state that is party to a convention of which the construction and interpretation is in question in the dispute. ${ }^{150}$ Secondly, Article 62 allows for a state that considers it has an interest of a legal nature which may be affected by the decision in the case to request to be allowed to intervene, which the Court will then decide upon. ${ }^{151}$ While intervention is also open to Respondent Pool members, it is unlikely that they would choose to avail of it.

AOSIS members that cannot be applicants could seek to intervene under Article 63 as they are all parties to both the UNFCCC and the Paris Agreement. To the nine AOSIS members that have submitted optional clause declarations, this could add another twentyeight AOSIS members. ${ }^{152}$ Article 63 interventions are rare, although New Zealand successfully intervened in Whaling in the Antarctic. ${ }^{153}$ In its analysis, the Court reaffirmed that Article 63 confers a 'right' to be admitted to the proceedings, so long as the declaration seeking to exercise this right falls within the provisions of Article 63. ${ }^{154}$ This implies that a state can be admitted even when one of the original parties objects. ${ }^{155}$ Importantly for AOSIS, judgements are binding upon states that intervene under Article $63 .{ }^{156}$

Article 62 is a less promising tool. ${ }^{157}$ The Rules of Court require that a State applying to intervene under Article 62 must set out 'any basis of jurisdiction which is claimed to exist as between the State applying to intervene and the parties to the case'. ${ }^{158}$ AOSIS members would be unable to set out any such basis. However, in Land, Island and Maritime Boundary Dispute, a Chamber of the Court concluded that the absence of a jurisdictional link is not a bar to permission being given for intervention that does not confer the status of party. ${ }^{159}$ This conclusion was affirmed by the full Court in Land and Maritime Boundary between Cameroon and Nigeria and Sovereignty over Pulau Ligitan and Palau Sipidan. ${ }^{160}$ The

150 ICJ Statute (n 13) art 63.

151 ibid art 62.

152 Antigua and Barbuda; Bahamas; Belize; Comoros; Cuba; Fiji; Grenada; Guyana; Jamaica; Kiribati; Maldives; Nauru; Palau; Papua New Guinea; Samoa; Singapore; Seychelles; Sao Tome and Principe; Solomon Islands; Saint Kitts and Nevis; Saint Lucia; Saint Vincent and the Grenadines; Tonga; Trinidad and Tobago; Tuvalu; Vanuatu.

153 Whaling in the Antarctic (Australia v Japan) (Declaration of Intervention of New Zealand) ICJ Reports 228 [2014].

154 ibid para 8.

155 Thirlway (n 100) 179.

156 ICJ Statute (n 13) art 63(2).

157 See Thirlway (n 100) 181-183; For a critique of Article 62 and suggestions for reform see Antonio Cassese, 'The ICJ: It is High Time to Restyle the Respected Old Lady' in Antonio Cassese (ed), Realising Utopia: The Future of International Law (2012), 242-3.

158 Rules of the Court (n 139) art 81(c).

159 Land, Island and Maritime Frontier Dispute (El Salvador/Honduras) (Application by Nicaragua for Permission to Intervene) ICJ Reports [1990] 92, 135.

${ }^{160}$ Land and Maritime Boundary between Cameroon and Nigeria, and Sovereignty (Cameroon $v$ Nigeria), (Application by Equatorial Guinea for Permission to Intervene) ICJ Reports [1999]; Sovereignty over Pulau Ligitan and Palau Sipidan (Indonesia/Malaysia) (Application by the Philippines for Permission to Intervene) ICJ Reports [2001]. 
same twenty-eight AOSIS members could, therefore, be allowed to intervene, at the Court's discretion, but, as they wouldn't be parties to the dispute, they could not enforce the judgement against the respondents. ${ }^{161}$ Thus, even if the Court allowed the interventions, it is better to rely on Article 63 as a basis for intervention.

Twenty-eight interventions under Article 63 would be an unprecedented occurrence, yet there is nothing preventing it. A climate case before the ICJ would involve the interpretation of both the UNFCCC and the Parties Agreement, the states concerned are parties to both and so carry a right to intervene, have their cases heard, and be bound to the judgement.

\section{ii. Section Conclusion}

Conferring jurisdiction by way of special agreement or compromissory clause appears impossible. The optional clause system allows for nine AOSIS members to bring a case against a group of thirty-three states from the Respondent Pool. The remaining Respondent Pool members could potentially be brought within the proceedings by virtue of forum prorogatum. Although this depends entirely on the states themselves and thus may be unlikely, it is neither impossible nor unprecedented. For AOSIS, twenty-eight members have a right to intervene under Article 63 ICJ Statute on the basis that they are parties to both the UNFCCC and the Paris Agreement. While unprecedented, if the AOSIS members decided to seek intervention, it appears that such intervention would be permissible.

By working together, the jurisdictional obstacles that an AOSIS Member would face individually at the ICJ can be overcome. It is possible for AOSIS members to bring a case that names all members of the Respondent Pool. Intervention appears more likely to achieve results than forum prorogatum, but, even if both fail, at the very least a case can definitely involve nine AOSIS Members against thirty-three respondents. Moreover, if intervention was to fail, the dispute settlement system under UNCLOS ${ }^{162}$ presents other options for AOSIS. Those AOSIS members who would be forced to pursue intervention at the ICJ may even prefer to forgo this in favour of bringing a case directly under UNCLOS. It is the UNCLOS system that attention now turns to.

\section{B. Dispute Settlement under UNCLOS}

The UNCLOS is one of an extremely small number of treaties that prescribe mandatory jurisdiction for disputes arising from the interpretation and application of its terms, something notably lacking from the UNFCCC regime. ${ }^{163}$ Its creation has been hailed as one of the most significant developments in dispute settlement in international law, even as important as the entry into force of the UN Charter, ${ }^{164}$ and has been described as 'the most significant regime for the settlement of disputes, in general, found in modern multilateral agreements' ${ }^{165}$ A climate case can be based, solely or in part, upon the UNCLOS. Thus, the dispute settlement system under the UNCLOS provides another important avenue for AOSIS. Following the strategy proposed by this article, AOSIS members that have not submitted declarations recognising the jurisdiction of the ICJ should seek to bring a joint claim under the UNCLOS system. While the UNCLOS provides for multiple fora, the approach entails utilising ITLOS by those AOSIS members

161 Land, Island and Maritime Frontier Dispute (n 159).

162 UNCLOS (n 6).

${ }^{163}$ Natalie Klein, Dispute Settlement in the UN Convention on the Law of the Sea (Cambridge University Press 2009) 2; Boyle (n 8) 831.

164 ibid.

165 Jonathan Charney, 'Entry into Force of the 1982 Convention on the Law of the Sea' 35 Virginia Journal of International Law (1995) 381, 389. 
able to do so, with those who fall outside its jurisdiction resorting to an Annex VII arbitral tribunal. Alternatively, an Annex VIII special arbitral tribunal, which is available for disputes relating to fisheries, environment, scientific research, and navigation, can be chosen if the relative parties so wish. This Section discusses the jurisdictional issues that call for this approach.

\section{i. Jurisdiction}

UNCLOS' Part XV dispute settlement procedures can only be resorted to where no settlement has been reached by other means. ${ }^{166}$ States are free to choose any means indicated in Article 33(1) UN Charter, i.e. 'negotiation, enquiry, mediation, conciliation, arbitration, judicial settlement, resort to regional agencies or arrangements, or other peaceful means of their own choice'. ${ }^{167}$ States are required to 'proceed expeditiously to an exchange of views' regarding the settlement of a dispute. ${ }^{168}$ In Southern Bluefin Tuna, ITLOS stated that whether the exchange has been undertaken is a subjective determination for the states themselves, with the requirement being satisfied when a state concluded that the possibilities of settlement, without recourse to the UNCLOS procedures, had been exhausted. ${ }^{169}$ ITLOS confirmed the subjective approach in MOX Plant and Land Reclamation, ${ }^{170}$ although also indicated that the assessment of the State still had to be reviewed. ${ }^{171}$ AOSIS members would simply have to be satisfied that the possibilities for settlement without recourse to the UNCLOS have been exhausted, for instance, as climate negotiations have been unsatisfactory and the ICJ is not available.

No additional form of consent to the Part XV procedures is required once a state is party to the UNCLOS and, once this is done, 'unilateral action is sufficient to vest the court or tribunal with jurisdiction, and that court or tribunal may render a decision whether or not the other party participates in the process'. ${ }^{172}$ However, the UNCLOS contains some potential bars to jurisdiction. Under Article 281, if states have selected their own means of dispute settlement, UNCLOS procedures will only apply if no resolution is reached through that means and if the parties have not excluded any further procedure. ${ }^{173}$ Further, according to Article 282 UNCLOS, arrangements under another agreement that produces a binding decision will apply in lieu of the UNCLOS procedures unless the parties agree otherwise. ${ }^{174}$ Thus, it may be that states that have accepted the compulsory jurisdiction of the ICJ by virtue of Article 36(2) ICJ Statute would be precluded from pursuing compulsory procedures under the UNCLOS without agreement by the parties to the contrary. However, viewing Article 36 declarations as unilateral actions means that 'the mere acceptances do not, of course, constitute any agreement as between states forcing them to refer a given dispute to the ICJ. The declarations express a willingness to accept

\footnotetext{
166 UNCLOS (n 6) art 296; Boyle (n 8) 837.

167 UNCLOS (n 6) arts 279, 280; UN Charter (n 92) art 33(1).

168 UNCLOS (n 6) art 282.

169 Southern Bluefin Tuna (New Zealand v Japan; Australia v Japan) (Requests for Provisional Measures) ITLOS Reports [1999] (Southern Bluefin Tuna), para 60.

170 The MOX Plant Case (Ireland v UK) (Provisional Measures) ITLOS Reports [2001], para 68; Case Concerning Land Reclamation by Singapore in and around the Straits of Johor (Malaysia $v$ Singapore) (Request for Provisional Measures) ITLOS Reports [2003] (Land Reclamation), para 48.

171 Land Reclamation (n 170) para 48.

172 Myron Nordquist, Shabtai Rosenne and Louis Sohn (eds) United Nations Convention on the Law of the Sea 1982: A Commentary Volume 5 (1989) 39.

173 UNCLOS (n 6) art 281; Boyle (n 8) 837.

174 UNCLOS (n 6) art 282; Boyle (n 8) 837.
} 
the jurisdiction if another State having made a declaration institutes proceedings' ${ }^{175}$ It is more likely that Article 282 UNCLOS is triggered when both states have submitted Article 36 ICJ Statute declarations. ${ }^{176}$

The previous analysis of Article 14 UNFCCC is also applicable here. Again, it is impossible to say with certainty what a court or tribunal would decide. At worst, it would rule that it lacks jurisdiction. At best, it would disregard the UNFCCC and hear the case on the basis that it has been brought under the UNCLOS Part XV and involves only the application of the UNCLOS. ${ }^{177}$ In Southern Bluefin Tuna, an Annex VII Arbitral Tribunal ruled that the parties to the dispute had agreed through the Convention for the Conservation of Southern Bluefin Tuna ${ }^{178}$ (CSBT Convention) to exclude any dispute from being initiated under UNCLOS Part XV. ${ }^{179}$ This ruling has been heavily criticised. ${ }^{180}$ It is not binding on future tribunals and it is hoped and anticipated that future tribunals, and ITLOS, would not follow it. ${ }^{181}$ Moreover, the CSBT Convention process required the parties to continue their efforts to reach agreement on a mutually acceptable process, whereas the UNFCCC Article 14 process has a definite endpoint: a conciliation commission report of recommendations. However, the parties may not accept the recommendations and so the case may not be resolved. Therefore, there would appear to be no legal impediment to a party initiating a dispute under the UNCLOS Part XV, even if it was considered to be one to which the UNFCCC would take precedence. ${ }^{182}$ Much depends on the strength of the case being made by AOSIS as 'Courts do not usually throw out good cases on jurisdictional grounds if they can avoid doing so'. ${ }^{183}$

Article 287 UNCLOS lists four courts and tribunals: ITLOS, ICJ, an arbitral tribunal, and a special arbitral tribunal. ${ }^{184}$ States may specify one or more of these as its preferred forum. ${ }^{185}$ If the parties have accepted the same forum, then this procedure will apply unless the parties agree otherwise. ${ }^{186}$ If the choices are not the same, or if a party has not indicated a preference, the dispute will be dealt with by an Annex VII arbitral tribunal. ${ }^{187}$

Table 5 shows the AOSIS and Respondent Pool members that have ratified UNCLOS and chosen ITLOS as their preferred forum. ${ }^{188}$ It is seen that five AOSIS members could thus bring a claim against sixteen Respondent Pool members before ITLOS.

175 Shabtai Rosenne, 'The Case-Law of ITLOS (1997-2001): An Overview' in Myron Nordquist and John Norton Moore (eds), Current Marine Environmental Issues and the International Tribunal for the Law of the Sea (2001) 139.

176 Klein (n 163) 44.

177 Boyle (n 8) 838.

178 Convention for the Conservation of Southern Bluefin Tuna (adopted 10 May 1993, entered into force 20 May 1994) UNTS 1819.

179 Southern Bluefin Tuna (n 169) para 57.

${ }^{180}$ Doelle (n 8) 330; Boyle (n 8).

181 ibid.

182 Doelle (n 8) 331.

${ }^{183}$ Boyle (n 8) 838; see also Doelle (n 8) 330; B Kwiatkowska, 'The Australia and New Zealand v Japan Southern Bluefin Tuna (Jurisdiction and Admissibility) Award of the First Law of the Sea Convention Annex VII Arbitral Tribunal' 16 International Journal of Marine and Coastal Law (2001) 239, 240.

${ }^{184}$ UNCLOS (n 6) art 287(1).

185 ibid.

186 ibid.

187 ibid arts 287(3) and arts 287(5); see Alabi (n 8) 219.

188 See UN Division for Ocean Affairs and the Law of the Sea, 'Settlement of disputes mechanism' $<$ https://www.un.org/depts/los/settlement_of_disputes/choice_procedure.htm> accessed 30 December 2020. 
Table 5

ITLOS (UNCLOS)

AOSIS
Cabo Verde
Fiji
St. Vincent and the
Grenadines
Timor-Leste
Trinidad and Tobago

$\begin{array}{ll}\begin{array}{l}\text { Respondent Pool } \\ \text { Australia } \\ \text { Austria }\end{array} & \begin{array}{l}\text { Hungary } \\ \text { Italy } \\ \text { Bulgaria }\end{array} \\ \text { Latvia } \\ \text { Canada } & \text { Lithuania } \\ \text { Croatia } & \text { Mexico } \\ \text { Estonia } & \text { Netherlands } \\ \text { Germany } & \text { Portugal } \\ \text { Greece } & \text { Spain }\end{array}$

The remaining AOSIS members could bring a case against all members of the Respondent Pool, except Liechtenstein and Turkey, before an Annex VII arbitral tribunal. This is because all Respondent Pool members have ratified UNCLOS except Liechtenstein, Turkey, the US, and Iran. ${ }^{189}$ However, the US and Iran are parties to the Fish Stocks Agreement and so are subject to UNCLOS dispute settlement procedures, although only in relation to arguments based upon the Fish Stocks Agreement, as it applies the UNCLOS dispute resolution mechanism to any dispute under the Fish Stocks Agreement, even where one or more of the disputants are not Parties to UNCLOS. ${ }^{190}$ It is also notable that China and the EU can also be included as respondents before an Annex VII arbitral tribunal, as they too are parties to UNCLOS. ${ }^{191}$ Significantly, this is the only forum where China, the EU, Iran, and the US could be involved in proceedings without the use of forum prorogatum. The AOSIS and Respondent Pool members that could be involved in proceedings before an Annex VII arbitral tribunal are shown in Table 6.

189 UN Division for Ocean Affairs and the Law of the Sea, 'Chronological lists of ratifications of, accessions and successions to the Convention and the related $<$ https://www.un.org/depts/los/reference_files/chronological_lists_of_ratifications.htm> accessed 30 December 2020.

190 Fish Stocks Agreement (n 91) art 30(1).

191 ibid. 
Table 6

Annex VII arbitral tribunal (UNCLOS/Fish Stocks Agreement*)

AOSIS

$\begin{array}{lll}\begin{array}{l}\text { Antigua and } \\ \text { Barbuda } \\ \text { Bahamas }\end{array} & \text { Maldives } & \text { Tuvalu } \\ & \begin{array}{l}\text { Marshall } \\ \text { Islands }\end{array} & \text { Vanuatu } \\ \text { Barbados } & \text { Mauritius } \\ \text { Belize } & \text { Nauru } \\ \text { Comoros } & \text { Niue } \\ \text { Cook } & \text { Palau } \\ \text { Islands } & \text { Papua New } \\ \text { Cuba } & \text { Guinea } \\ \text { Dominica } & \text { Samoa } \\ \text { Dominican } & \text { Singapore } \\ \text { Republic } & \text { Seychelles } \\ \text { Federated } & \text { Seytes } & \\ \text { States } & \\ \text { Micronesia } & \\ \text { Grenada } & \text { Sao Tome } \\ & \text { and } \\ \text { Guinea- } & \text { Principe } \\ \text { Bissau } & \text { Solomon } \\ \text { Guyana } & \text { Islands } \\ \text { Haiti } & \text { St. Kitts } \\ \text { Jamaica } & \text { St. Lucia } \\ \text { Kiribati } & \text { Suriname } \\ & \text { Tonga }\end{array}$

\section{Respondent Pool}

Australia Germany New

Zealand

Austria Greece Norway

Belarus Hungary Poland

Belgium Iceland Portugal

Brazil India Romania

Bulgaria Indonesia Russia

Canada Iran* Slovakia

China Ireland Slovenia

Croatia Italy Spain

Cyprus Japan Sweden

Czech Latvia Switzerland

Republic

Denmark Liechtenstein Ukraine

Estonia Luxembourg UK

EU Malta US*

Finland Monaco

France Netherlands

As an alternative to ITLOS or an Annex VII arbitral tribunal, an Annex VIII special arbitral tribunal can be elected. From AOSIS, only Timor-Leste has indicated a preference for an Annex VIII special arbitral tribunal, with Belarus, Mexico, Portugal, Russia, and Ukraine from the Respondent Pool having done so. ${ }^{192}$ The attractiveness of Annex VIII tribunals is that the arbitrators are preferably to be chosen from four lists of experts for each of the categories of dispute covered by Annex VIII: fisheries, environment, scientific research, and navigation. ${ }^{193}$ The preference for experts means that the arbitrators need not be, and probably will not be, legally qualified. ${ }^{194}$ Another potentially attractive feature of Annex VIII tribunals for a climate change case is that they may be used at any time, if the parties to the dispute so agree, 'to carry out an inquiry and establish the facts giving rise to

${ }^{192}$ List of States choices of procedure at UN Division for Ocean Affairs and the Law of the Sea, 'Settlement of disputes mechanism' (n 188).

${ }^{193}$ UNCLOS (n 6) art 2(1).

${ }^{194}$ Robin Churchill, 'The General Dispute Settlement System of the UN Convention on the Law of the Sea: Overview, Context, and Use' 48(3-4) Ocean and Development Law (2017) 216, 220. 
the dispute'. ${ }^{195}$ An Annex VIII tribunal may be better suited than ITLOS or an Annex VII tribunal to deal with disputes of particular scientific and technical difficulty. A dispute under UNCLOS and/or the Fish Stocks Agreement regarding the effect of climate change upon the marine environment and/or fish stocks would seem to be such a dispute. The lack of favour for Annex VIII as a forum of preference makes its utilisation unlikely. Nevertheless, the option remains open to Timor-Leste.

Finally, it is possible, and not uncommon, for disputes that are subject to compulsory arbitration to subsequently be submitted to ITLOS pursuant to an agreement concluded by the parties after the institution of arbitral proceedings. ${ }^{196}$ Such a situation has occurred in five contentious cases. ${ }^{197}$ Additionally, intervention in a case before ITLOS is possible. Articles 31 and 32 Statute of the International Tribunal for the Law of the Sea ${ }^{198}$ (ITLOS Statute) provide for intervention in the same manner as Articles 62 and 63 ICJ Statute but with one difference: under both categories of intervention under the ITLOS Statute the intervenor is bound by the decision. ${ }^{199}$ Both a decision on whether to transfer a case from an arbitral tribunal to ITLOS, and whether or not to attempt to intervene is ultimately one for the relevant parties.

\section{ii. Section Conclusion}

It has been contended that the barriers to jurisdiction within UNCLOS, Articles 281 and 282, will not be triggered by the envisaged litigation as the AOSIS members that would bring a case under the UNCLOS Part XV procedure have not submitted optional clauses in regards to the ICJ and it is contended that Article 14(2) UNFCCC is not applicable. Thus, after having satisfied themselves that other avenues have been exhausted and that an exchange of views on this matter has been undertaken, five AOSIS Members could bring a case against nine Respondent Pool states before ITLOS. The remaining thirty-four AOSIS Members that cannot directly bring a claim before either the ICJ or ITLOS, could bring a case against the entire Respondent Pool, except Liechtenstein and Turkey, to an Annex VII arbitral tribunal. The option of an Annex VIII tribunal is only open to TimorLeste.

\section{Conclusion}

This Section has discussed the jurisdictional framework of both the ICJ and the dispute settlement procedure under UNCLOS Part XV. The value of a multi-party litigation strategy spearheaded by AOSIS has been illustrated, which ultimately affords the opportunity for all AOSIS member states to be involved in litigation against all members

195 UNCLOS (n 6) art 5(1).

196 Patibandla C Rao and Philippe Gautier, The International Tribunal for the Law of the Sea: Law, Practice and Procedure (2018) 106.

$197 M / V$ 'SAIGA' (No 2) (St Vincent and the Grenadines v Guinea) ITLOS Reports 1999; Conservation and Sustainable Exploitation of Swordfish Stocks (Chile/European Union) ITLOS Reports 2009; Delimitation of the marine boundary in the Bay of Bengal (Bangladesh/Myanmar) ITLOS Reports 2012; $M / V$ 'Virginia G' (Panama/Guinea-Bissau) ITLOS Reports 2014; Dispute Concerning Delimitation of the Maritime Boundary between the Republic of Ghana and the Republic of Cote d'Ivoire in the Atlantic Ocean (Ghana/Cote d'Ivoire) ITLOS Reports 2017.

198 UNCLOS (n 6); Annex VI Statute of the International Tribunal for the Law of the Sea (UNCLOS Annex VI) arts 31-32.

199 UNCLOS (n 6) arts 31(3) and 32(3). 
of the Pool, except potentially Turkey, ${ }^{200}$ before at least one forum. Possible solutions for overcoming the barriers themselves have been offered, namely through forum prorogatum and intervention.

\title{
V. Concluding Remarks
}

An innovative Blueprint for bringing the world's first international multi-party climate change case has been laid out. The jurisdictional barriers associated with climate change litigation have been shown to be far from insurmountable. AOSIS has been identified as an ideal group to bring such litigation. The group has been instrumental in climate change negotiations. While individual members have pondered climate change litigation in the past, none have followed through, being dissuaded not least by jurisdictional barriers. Together AOSIS can overcome these barriers, bringing parallel cases before the ICJ, ITLOS, and arbitral tribunals. Those AOSIS members capable of doing so can initiate proceedings, with others then allowed to join through the doctrine of intervention. Similarly, cases can be brought against groups from the Respondent Pool, with the inclusion of the rest being sought through forum prorogatum. Importantly, it is guaranteed that all Respondent Pool members, bar Turkey, would be involved in proceedings before at least one court or tribunal. This includes the infamously evasive high emitting China and the US as well as the intriguing option of the EU. It is impossible to determine for certain what conclusion a court or tribunal would come to at the merits state, and such pondering is beyond the scope of this thesis. Nevertheless, given the technological and scientific developments regarding climate change, as well as universal consensus (a minority of, albeit some powerful, deniers withstanding) it is surely a timely and worthwhile pursuit for AOSIS to utilise the Blueprint and make the world's first international multi-party climate change case a reality.

\author{
www.grojil.org
}

${ }^{200}$ Turkey has not submitted an optional clause declaration accepting the jurisdiction of the ICJ and is a party to neither UNCLOS nor the Fish Stocks Agreement. Turkey would have to submit to a forum prorogatum request. 